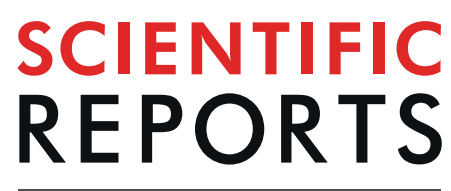

natureresearch

Check for updates

\title{
OPEN The Lipocalin2 Gene is Regulated in Mammary Epithelial Cells by NF $\kappa B$ and C/EBP In Response to Mycoplasma
}

\begin{abstract}
Wei Zhao ${ }^{1,2,3}$, Lee Bendickson ${ }^{1} \&$ Marit Nilsen-Hamilton ${ }^{1,2 凶}$
Lcn2 gene expression increases in response to cell stress signals, particularly in cells involved in the innate immune response. Human Lcn2 (NGAL) is increased in the blood and tissues in response to many stressors including microbial infection and in response to LPS in myeloid and epithelial cells. Here we extend the microbial activators of Lcn 2 to mycoplasma and describe studies in which the mechanism of Lcn2 gene regulation by MALP- 2 and mycoplasma infection was investigated in mouse mammary epithelial cells. As for the LPS response of myeloid cells, Lcn2 expression in epithelial cells is preceded by increased TNF $\alpha$, IL- 6 and I $\kappa B \zeta$ expression and selective reduction of $I \kappa B \zeta$ reduces $L c n 2$ promoter activity. Lcn2 promoter activation remains elevated well beyond the period of exposure to MALP- 2 and is persistently elevated in mycoplasma infected cells. Activation of either the human or the mouse Lcn2 promoter requires both NFKB and C/EBP for activation. Thus, LCn2 is strongly and enduringly activated by mycoplasma components that stimulate the innate immune response with the same basic regulatory mechanism for the human and mouse genes.
\end{abstract}

Epithelial cells are the first responders to many pathogenic bacteria and stress conditions in vivo. The innate immune response, the first line of defense in the inflammatory response, involves activation of the tran-

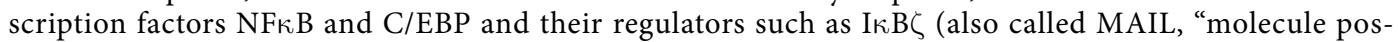
sessing ankyrin-repeats induced by lipopolysaccharide" or INAP, "IL-1-inducible nuclear ankyrin-repeat protein" $)^{1-3}$. Inflammation aids in the resolution of infection and also promotes tissue repair, partly by way of the proteins secreted during the process. For example, Lcn2 is highly upregulated in the kidney in response to ischemia-reperfusion injury and macrophages are stimulated by sphingosine-1-phosphate to release Lcn2, which can promote tissue repair ${ }^{4,5}$. Lcn 2 is produced by the kidney epithelium ${ }^{6}$ and by epithelial cells from other tissues such as the uterus, mammary gland, liver, stomach, small intestine, colon and lung, both during normal physiological changes that provide opportunities for pathogen invasion and in response to pathogens and other stress inducers ${ }^{4,7-11}$. Lcn 2 expression is increased in HeLa cells in response to M. hominis ${ }^{12}$. However, although there are many examples of Lcn2 response to LPS [Ibid], the response of epithelial cells of normal tissue origin to MALP-2 or mycoplasma to other pathogenic bacterial forms, such as mycoplasma has not to our knowledge been reported.

Mycoplasma spp. are intimately involved in diseases that affect humans ${ }^{13}$ and livestock ${ }^{14}$. Various mycoplasma species are associated with and/or cause diseases including pneumonia, mastitis, arthritis, otitis, genital disorders and keratoconjunctivitis. In humans, several mycoplasma species have been linked to cancer ${ }^{15-28}$. The primary contribution of mycoplasma to cancer and other diseases is most likely their inflammatory properties, which are mediated by the interaction of the lipopeptide MALP- 2 with the Toll-like receptor, TLR2/629-38. Cultured cells infected with mycoplasma adopt more cancer-like phenotypes that include activated signaling pathways for proliferation, stimulated migration and the epithelial to mesenchymal transition ${ }^{18,19,21,34,39,40}$. Because mycoplasma infections are important in disease and frequently found in cultured cells that have not been adequately

${ }^{1}$ Roy J Carver Department of Biochemistry, Biophysics and Molecular Biology and the Interdepartmental Molecular, Cellular and Developmental Biology Program, lowa State University, Ames, IA, 50011, USA. ${ }^{2}$ Interdepartmental Molecular, Cellular and Developmental Biology Program, lowa State University, Ames, IA, 50011, USA. ${ }^{3}$ Present address: Bayview Physicians Group, Battlefield Medical association, 675 North Battlefield Boulevard, Chesapeake, VA, 23320, USA. ${ }^{\circledR e}$-mail: marit@iastate.edu 
monitored, it is important to understand how these organisms regulate the expression of genes such as Lcn 2 that have many reported functions in tissue repair and that are routinely used as monitors of disease status ${ }^{41-45}$.

HC11 epithelial cells, derived from the mouse mammary gland, were chosen for these studies as they possess many characteristics of normal differentiated mammary epithelial cells and Lcn 2 is highly expressed during lactation and involution of the mammary gland ${ }^{9,46,47}$. Here we show that $\mathrm{Lcn} 2$ gene expression is increased by mycoplasma infection and by MALP-2, the mycoplasma lipopeptide. Activation of the primary response genes $\mathrm{NF} \kappa \mathrm{B}, \mathrm{C} / \mathrm{EBP}$, and $\mathrm{I} \kappa \mathrm{B} \zeta$ precedes $\mathrm{Lcn} 2$ activation and the $\mathrm{Lcn} 2 \mathrm{mRNA}$ continues to increase for at least $72 \mathrm{~h}$ after addition of MALP-2 for which the continued presence of MALP-2 is required. The presence of $\mathrm{I} \kappa \mathrm{B} \zeta$ is required for Lcn 2 activation by MALP-2. The mouse and human Lcn 2 promoters contain proximal NFKB and the C/EBP regulatory elements and the deletion of either element eliminates promoter activation by MALP-2. Thus, Lcn2 responds to inflammatory signals from pathogenic bacteria and mycoplasma by a mechanism that requires $\mathrm{I} \kappa \mathrm{B} \zeta$ and involves the direct cooperation of NFKB and C/EBP on the Lcn 2 promoter.

\section{Results}

Gene expression induced by MALP-2. MALP-2 increases the expression of IL-6 and TNF $\alpha$ in HC11 cells, with TNF $\alpha$ gene expression responding to MALP-2 with a peak about one hour earlier than IL6 expression (Fig. 1A). The responses to MALP-2 of these two genes were of a similar elevation as observed after the addition of LPS except that the increase in TNF $\alpha$ mRNA peaked $\sim 1 \mathrm{~h}$ sooner in response to MALP- 2 than in response to LPS (Fig. 1A) The response of Lcn2 was slower than for IL-6 and TNF $\alpha$ and unlike for these latter genes, Lcn2 expression continued to increase over the course of at least $72 \mathrm{~h}$ but only when MALP- 2 was present throughout the experiment. When MALP-2 was removed after $4 \mathrm{~h}, \mathrm{Lcn} 2$ gene expression remained elevated over the remaining $68 \mathrm{~h}$ of the experiment (Fig. 1B). The half-maximal response of Lcn2 expression to MALP-2 in HC11 cells, determined using a nonlinear fit model from an average of four independent experiments, was $320 \mathrm{pM}$ $\left(\mathrm{R}^{2}=0.96\right.$; Fig. 1C). The increased Lcn 2 mRNA levels were accompanied by appearance of $\mathrm{Lcn} 2$ in the medium of cells treated with MALP-2 or LPS (Fig. S1) These results show that MALP-2 is a potent inducer of inflammatory response genes and that Lcn 2 expression continues to increase for many hours in the presence of MALP-2 and was persistently elevated even after the removal of MALP-2. In contrast, the increased expression of the two cytokines, IL6 and TNF $\alpha$ was rapidly quenched even in the continued presence of MALP-2.

Elevated expression of inflammatory response genes in mycoplasma infected cells. The identification of a naturally mycoplasma-infected HC11 cell culture afforded the opportunity of investigating the effect of chronic mycoplasma contamination on epithelial cells and on the expression of Lcn2. The mycoplasma was identified as M. arginini by the sequence of its $16 \mathrm{~S}$ rDNA and the cells were freed of M. arginini with a BM-cyclin regime. A newly infected cell subline was created using filtered conditioned medium from the parent infected cells. The infection status of each cell subline was verified by PCR (Fig. 2A). All cell sublines exhibited similar epithelial-type morphology and growth rates (Fig. 2B,C).

Expression levels of TNF $\alpha$, IL-6 and Lcn2, determined by RT-qPCR, were higher in the two cell sublines infected with M. arginini than in the cured, uninfected cells (Fig. 2D). The elevation of Lcn2 expression in chronically infected cells is consistent with the observed persistent increase in Lcn2 gene expression and the remaining elevation of IL6 and TNF $\alpha$ after $4 \mathrm{~h}$ in response to MALP-2 (Fig. 1). We also tested the effect of Mycoplasma fermentans, which is one of the 5 species that accounts for more than $90 \%$ of cell culture contaminations. HC11 cells infected with $M$. fermentans showed similar increases in the mRNAs of Lcn2, TNF $\alpha$, and IL-6 as HC11 cells contaminated with M. arginini compared with uninfected cells (Fig. 2E).

NF $\kappa B$ and C/EBP response elements are necessary for $M$. arginini and MALP-2 induced mouse and human Lcn2 gene expression. To investigate the mechanism by which MALP- 2 and M. arginini regulate Lcn2 expression we used mouse and human Lcn2 promoters driving the expression of luciferase as a reporter. A comparison of the activities of a range of truncated mouse Lcn2 promoters showed that the shortest length of promoter to respond to mycoplasma infection was a $253 \mathrm{bp}$ fragment containing the NF $\kappa \mathrm{B}$ and $\mathrm{C} / \mathrm{EBP}$ response elements (Fig. 3A). This is consistent with previous observations that NFKB and C/EBP elements are important for Lcn 2 induction by IL- $1 \beta$ and LPS ${ }^{48,49}$.

To test if one or both NFKB and C/EBP elements are required for promoter responsiveness to MALP-2 and $M$. arginini infection, reporter plasmids were constructed of the mouse and human promoters in which one or both sites were mutated to sequences known not to be bound by the respective transcription factor. These reporter genes were transfected into mycoplasma-free and M. arginini-infected cells. The mycoplasma-free cells were also treated with MALP-2 to determine the requirement of one or both elements for stimulating Lcn2 promoter activity. The results showed that both NFKB and C/EBP elements are required for MALP-2 or M. arginini activation of both the mouse and human Lcn2 promoters (Fig. 3B,C).

We investigated which $\mathrm{C} / \mathrm{EBP}$ isoforms are expressed by $\mathrm{HC} 11$ cells by PCR and found evidence for the presence of $\mathrm{C} / \mathrm{EBP} \alpha, \beta$ and $\delta$ isoforms (Fig. S2). This observation is consistent with the reported isoforms expressed by their mammary gland origin ${ }^{50}$. We examined the effect of MALP-2 on the levels of each C/EBP isoform that was expressed and found no statistically significant increase in $\Delta \Delta \mathrm{Ct}$ (Student's Ttest) for their levels of expression with and without MALP-2 incubation for $24 \mathrm{~h}$. C/EBP is present in the nuclei of HC11 cells as expected of this transcription factor (Fig S2). However, unlike for some cells, NFkB was was not found to move extensively into the nucleus after treatment with MALP-2 or LPS. Instead a low level of NFKB was seen in the nucleus at all times with either treatment (Fig. S3).

I $\kappa B \zeta$ is a Downstream Regulator from MALP-2 of Lcn2 Expression. $\operatorname{I} \kappa B \zeta$ is a nuclear member of the

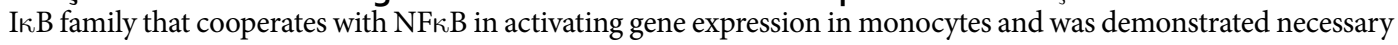



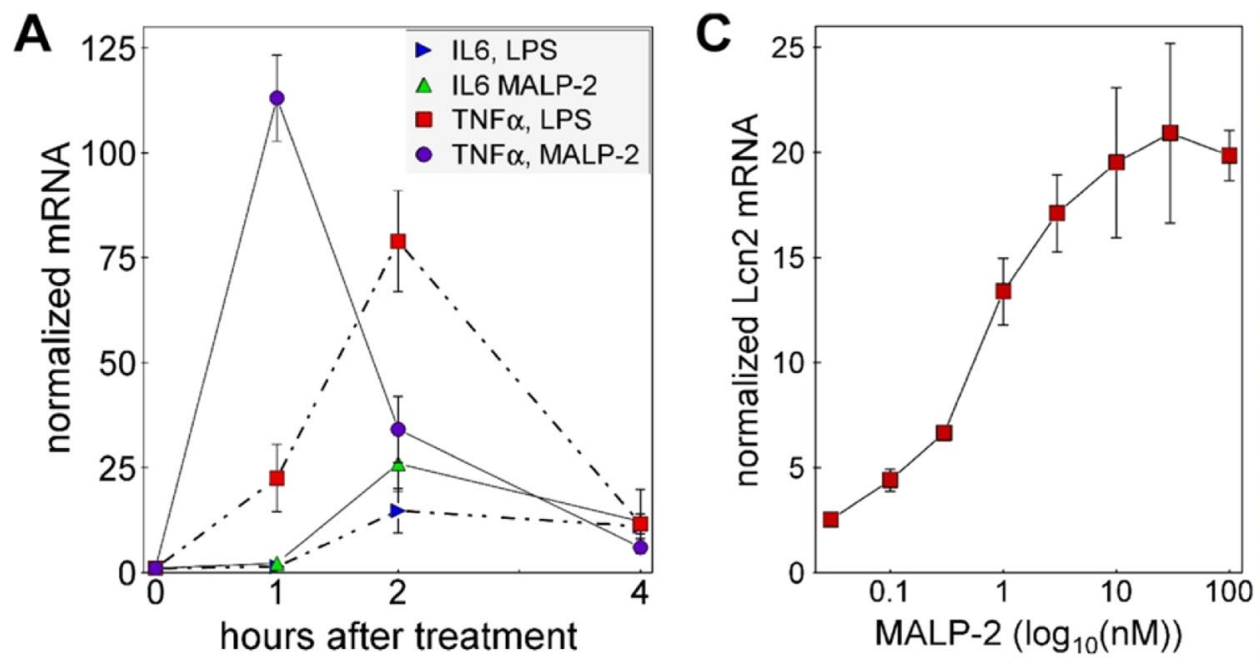

B

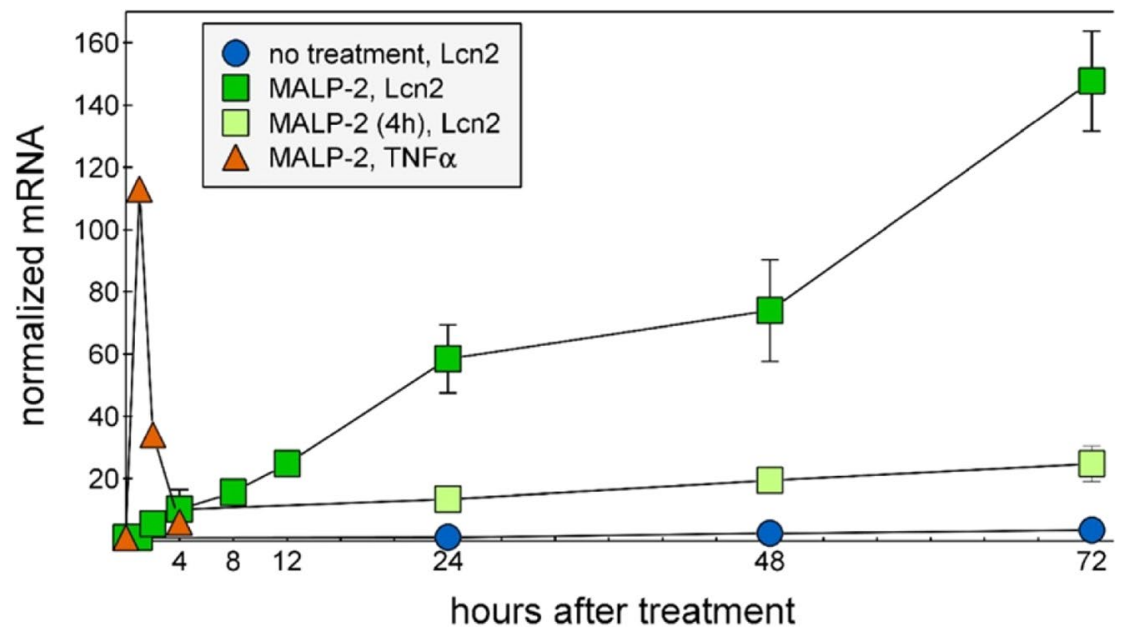

Figure 1. Stress-responsive genes and a persistent increase in Lcn2 expression induced by MALP-2. (A) HC11 cells were treated with LPS $(10 \mu \mathrm{g} / \mathrm{ml})$ or MALP-2 $(10 \mathrm{ng} / \mathrm{ml})$ for the indicated time periods and RNA samples prepared and quantified for IL-6, TNF $\alpha$ and cyclophilin mRNAs by RT-qPCR. The values for IL-6, TNF $\alpha$ were normalized to the cyclophilin values for the same sample and the zero time point for each gene set was used to normalize the results for all time points of that set. (B) HC11 cells were treated with $10 \mathrm{ng} / \mathrm{ml} \mathrm{MALP}-2$ for the time periods shown (MALP-2, Lcn2) or treated with MALP-2 for 4 hours then the cells were washed and the medium changed to the same medium lacking MALP-2 [MALP-2 (4h), Lcn2]. Lcn2, TNF $\alpha$ and cyclophilin mRNA levels were quantified by RT-qPCR and normalized to cyclophilin. (C) HC11 cells were treated with MALP-2 at various concentrations for $12 \mathrm{~h}$. Lcn 2 and cyclophilin mRNAs were then quantified by RT-qPCR. All values were normalized to the average control value from cells treated with vehicle.

for human Lcn2 promoter activation in human A549 cells by the combination of IL-17 and TNF ${ }^{51}$. I $\kappa$ B $\zeta$ mNA was tracked with time after addition of MALP-2 or LPS (Fig. 4A). As for the response of TNF $\alpha$, the increase in I $\kappa$ B $\zeta$ mRNA peaked about $1 \mathrm{~h}$ sooner after the addition of MALP- 2 than after LPS. These parallel time courses in response to both MALP-2 and LPS suggest a possible common mechanism of activation of these genes by both compounds.

To test if I $\mathrm{I} B$ is important for the activation by MALP-2 of Lcn2, the HC11 cells were transfected with short hairpin RNA $(\operatorname{shI} \kappa B \zeta)$. Lcn 2 promoter activity was decreased by $60 \%$ in $\mathrm{HC} 11$ cells stimulated by MALP- 2 that were transfected with the $253 \mathrm{bp}$ Lcn 2 promoter and cotransfected with $\mathrm{I} \kappa \mathrm{B} \zeta$ shRNA compared with those contransfected with the control SCH002 RNA (Fig. 4B). The specificity of shI $\kappa B \zeta$ in suppressing I $\kappa$ B $\zeta$ mRNA expression was established using, as a control, an $\mathrm{I} \kappa \mathrm{B} \zeta \mathrm{m}$ mRNA expression vector in which a silent mutation replaced the wildtype sequence in the region complementary to the shI $\kappa \mathrm{B} \zeta$ RNA. This mutant mRNA was not decreased by the transfected shI $\kappa$ B $\zeta$ mRNA (Fig. 4C).

\section{Discussion}

$\mathrm{Lcn} 2$ is an acute phase protein ${ }^{8}$ and its gene expression is increased in response to inflammatory signals in several epithelial tissues including the kidney, stomach, small intestines and lungs ${ }^{4,7-11}$. Increased tissue NGAL (human Lcn2) has been correlated with several diseases that involve stress and inflammation ${ }^{52}$, including kidney disease for which there is a well-studied mouse model $^{53}$. NGAL is also reported as a precocious marker for therapeutic 
A

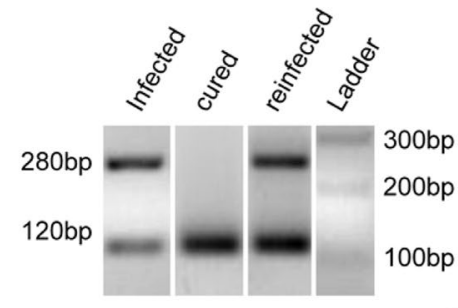

C

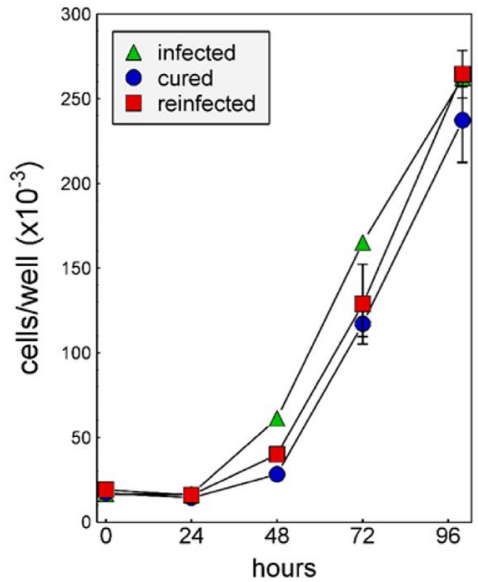

B

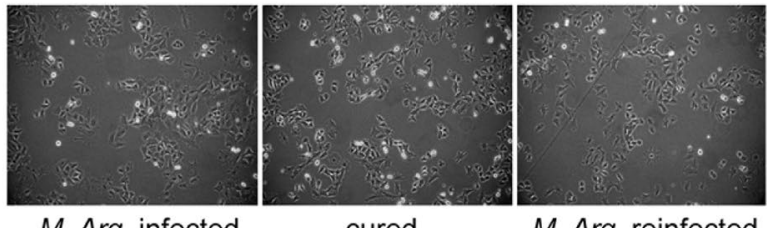

cured

M. Arg. reinfected
E

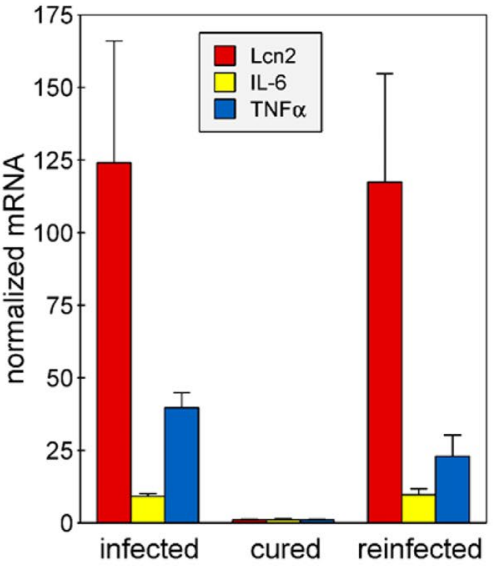

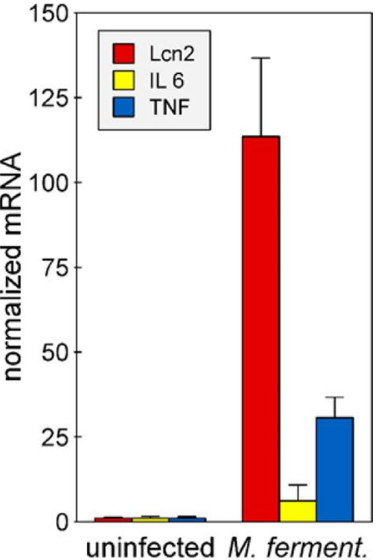

Figure 2. Effect of mycoplasma infection on HC11 cell growth, morphology and gene expression levels. (A) Genomic DNAs were amplified with primers targeting the $16 \mathrm{~S}$ rDNA of mycoplasma. PCR products were separated by electrophoresis through $2 \%$ agarose. The image shows that mycoplasma DNA was amplified from $M$. arginini-infected and reinfected cells, but not from the cured, mycoplasma-free cells. The image is compiled from two gels, which are shown in their entirety the Supplemental materials, (B) HC11 cells that were infected or reinfected with $M$. arginini, or uninfected (cured) were seeded on $10 \mathrm{~cm}$ plates. Pictures were taken $48 \mathrm{~h}$ after seeding. (C) HC11 cells, seeded in 24 well plates, were counted after different time periods using a coulter counter. Shown are the means \pm standard deviations $(\mathrm{SD})$ from duplicate wells at each time point from a representative experiment. (D,E) The expression levels of Lcn2, IL-6 and TNF $\alpha$ and cyclophilin in HC11 cells were quantified by RT-qPCR. The relative mRNA levels in all samples were normalized to those in uninfected (cured) cells. M. arg: M. arginini-infected cells cured: mycoplasma-free cells, reinfected: cells reinfected with $M$. arginini. M. ferment: M. fermentans infected cells.

response of renal and non-renal diseases ${ }^{54}$. As a result of these and many other studies, NGAL has been adopted as a blood marker for tissue inflammation and an indicator of kidney injury ${ }^{42,55-59}$.

In cell culture Lcn2 is induced by growth factors ${ }^{60,61}$, cytokines $^{7,62-64}$, LPS $^{11,65,66}$, glucocorticoids $9,66,67$, and MALP-2 (this work). The half maximal response to MALP-2 of $320 \mathrm{pM}$ is in the range of the half maximal responses of 30 to $70 \mathrm{pM}$ for E. coli $\mathrm{LPS}^{68-70}$, and $1.3 \mathrm{nM}$ for S. Minnesota LPS $^{70}$. This result is also consistent with a previous study showing that MALP-2 is a potent macrophage stimulatory lipopeptide that increases NO release from macrophages at concentrations in the picomolar range ${ }^{71}$. Lcn2 is expressed by epithelial cells, which coordinate with macrophages and dendritic cells to mount the innate immune response. These data show that epithelial cells are stimulated by the same concentration range of MALP- 2 that activates macrophages. Thus, it is expected that both epithelial cells and macrophages are activated by MALP-2 in vivo as a result of mycoplasma infection.

$\mathrm{Lcn} 2$ gene expression is activated in cells that mount the innate immune response including epithelial cells, dendritic cells, macrophages and neutrophils ${ }^{11,66,72}$. Mouse Lcn 2 has been demonstrated to suppress bacterial proliferation by complexing iron siderophores released by pathogens in an in vivo model ${ }^{73}$. Studies of rodent models have demonstrated that Lcn2 promotes tissue repair in the stomach ${ }^{4}, \mathrm{kidney}^{5,74}$, skeletal muscle ${ }^{75}$, and small intestine $^{76}$, Several effects of the Lcn 2 protein in cell culture may be linked to these in vivo observations, including effects of $\mathrm{Lcn} 2$ on cell proliferation and movement ${ }^{4,5,77}$. By contrast, $\mathrm{Lcn} 2$ is also associated with apoptotic defects in hematopoietic cells $\mathrm{s}^{78,79}$, promoting the epithelial mesenchymal transition ${ }^{80-82}$ and opposing cutaneous wound healing in diabetic mice ${ }^{83}$. Thus, the role of $\operatorname{Lcn} 2$ in vivo is likely to be complex and even cell type-dependent.

We examined the response of HC11 mammary-derived epithelial cells to mycoplasma and its MALP-2 product. As an externally exposed tissue, the mammary gland is susceptible to bacterial infection, which results in mastitis, an inflammatory condition that has been studied extensively in agricultural animals because of its large economic impact. Infections by pathogenic mycoplasma also induce persistent host inflammation ${ }^{84-87}$, which is consistent with the many reports of the association of mycoplasma infections and cancer ${ }^{15-28}$. In response to bacterial infection, epithelial cells, tissue-resident macrophages and dendritic cells (DCs) respond due to recognition of the PAMPs (pathogen associated molecular patterns) by pattern recognition receptors such as the Toll-like receptors (TLR $)^{88-90}$. The $M$. fermentans-derived lipopeptide, MALP-2, with the sequence (S-[2,3-bisacyl(C16:0/ C18:0;C18:1)-oxypropyl]cysteine-GNNDESNISFKEK, signals through TLR2 and TLR6 ${ }^{71,91,92}$. Activation of TLRs 
A

mouse

NFKB

C/EBP

human

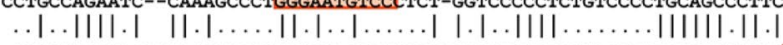

TGTTGCTCAACCT-TGCACAGTTCCGAC

human

-245 -AAGAAAGAAACAGCACAAGGAAGGCACAGAGGGAGTCGTTGTCCCTGCCAGAGGTGCAGCACTCCGC

$.|| \ldots|||\ldots||\ldots| \ldots \ldots|| .|$.

mouse

-158 CTGGGGA----GA-GAGGGACAGAAATCTTGCCAAGTATTTCAACAGAATGTACTGGCAATTACTTCATGGCTTCCTGGACTTGGTAAAGGATGGACTAC

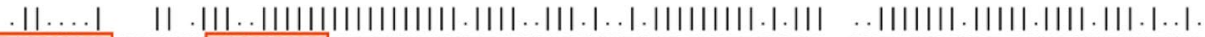

human -145 TTGCCCAATCCTGACCA GGTGCAGAAATCTTGCCAAGTGTTTCCGCAGGAGTTGCTGGCAATTGCCTCA--CATTCCTGGCCTTGGCAAAGAATGAATCAA C/EBP-1 C/EBP-2

\section{TATA}

mouse

-64 CCCGCCCAACAGGGGGCTGGCAGCCAGGTAGGCCCATAAAAAGCCGCTGGGGAGTCCTCCTCA +1

human

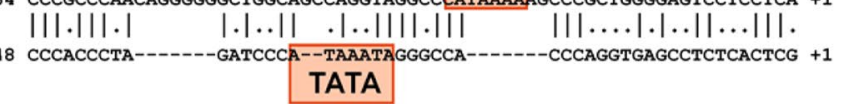

B

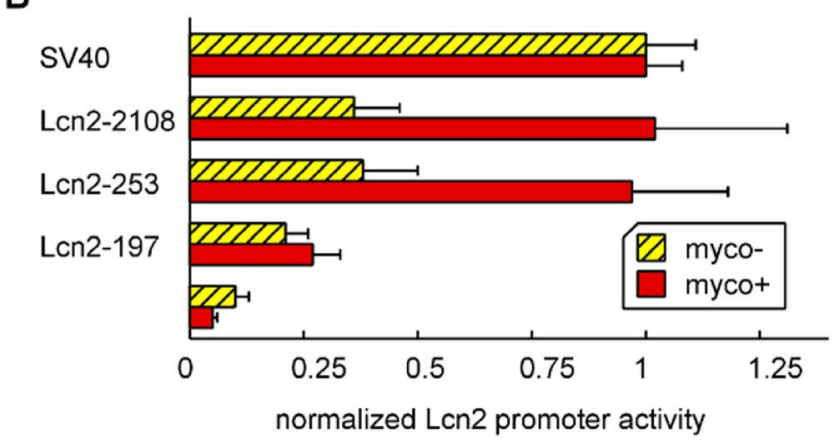

C

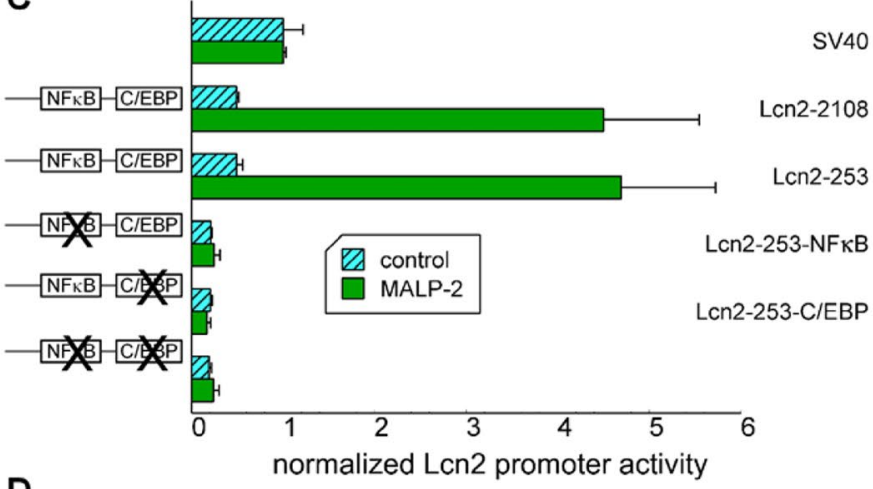

D

normalized Lcn2 promoter activity

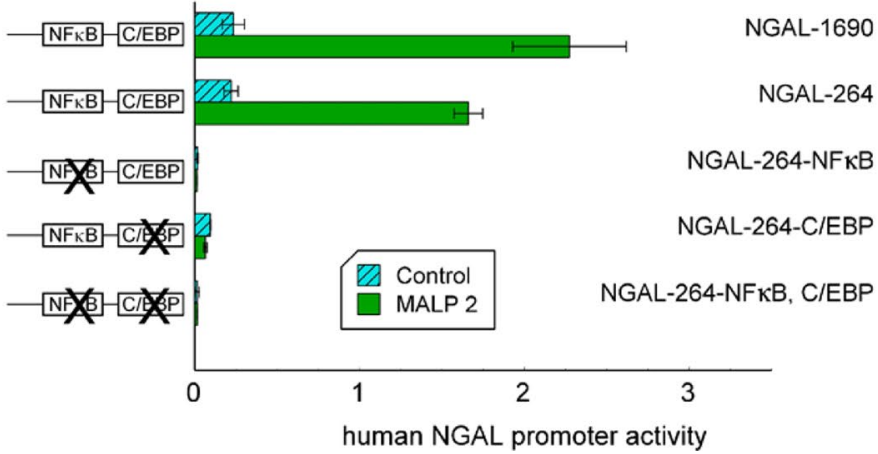

Figure 3. NFKB and C/EBP binding sites are required for MALP-2-induced Lcn2 expression from both the mouse and human promoters. (A) An alignment of human and mouse proximal promoters with the C/EBP and NFkB site identified. Human C/EBP-1 was mutated in this study. Sources of the sequences were GenBank: x81627 (mouse) and x99133 (human). (B) HC11 cells infected with mycoplasma (myco+) or uninfected (myco-) were co-transfected with a Renilla luciferase expression control plasmid and firefly luciferase reporter plasmids each containing one of a series of truncated $\mathrm{Lcn} 2$ promoters (starting at the listed gene position and ending at $+53 \mathrm{bp}$ ). The cells were harvested and measured for luciferase activity $48 \mathrm{~h}$ after transfection. The relative luciferase activities are shown normalized to the value obtained from cells transfected by a plasmid from which firefly luciferase expression was driven by the SV40 promoter. Lcn2-1477, Lcn2-1003, Lcn2-711 and Lcn2-438 had similar activity levels as Lcn2-2108 in M. arginini infected HC11 cells (data not shown). (C,D) HC11 cells were co-transfected with a Renilla luciferase expression control plasmid and a firefly reporter plasmid with one of the indicated Lcn 2 or NGAL promoter segments. Twenty-four hours after transfection the 
cells were treated with or without $10 \mathrm{ng} / \mathrm{ml}$ MALP-2, harvested $12 \mathrm{~h}$ later and measured for luciferase activity. Data was normalized to the Renilla transfection control. (B) Expression from the mouse Lcn2 promoter and mutant versions. (C) Expression from the NGAL promoter and mutant versions. (A-C) hatched bars, controls; red bars, $M$. arginini infected cells, green bars, MALP-2 treated uninfected cells.
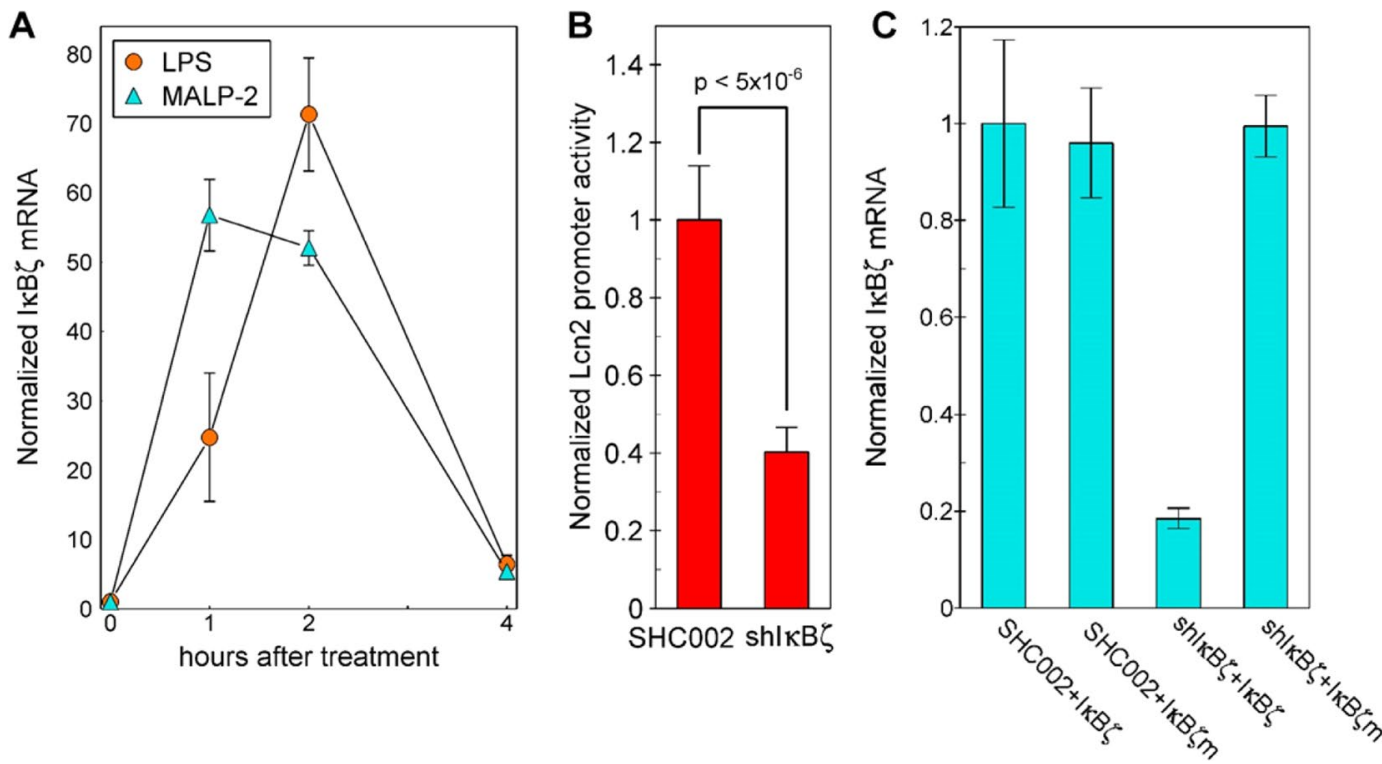

Figure 4. $I \kappa B \zeta$ is induced by MALP- 2 and regulates $L \mathrm{cn} 2$ promoter activity. (A) HC11 cells were treated with $10 \mu \mathrm{g} / \mathrm{ml}$ LPS or $10 \mathrm{ng} / \mathrm{ml}$ MALP-2. I $\kappa B \zeta$ mRNA was quantified by RT-qPCR and normalized to the cyclophilin mRNA in the same sample and then all values were normalized to the 0 -time point. (B) HC11 cells were cotransfected with the $253 \mathrm{bp} \mathrm{Lcn} 2$-luciferase plasmid and the Renilla-luciferase control plasmid in combination with a plasmid to express one of the following RNAs: SHC002 or shI $\kappa$ B $\zeta$. The transfected cells were treated with $10 \mathrm{ng} / \mathrm{ml}$ MALP-2 for $18 \mathrm{~h}$ then lysates tested for promoter activity. (C) HC11 cells were cotransfected with expression vectors for eGFP with the following combinations: $\operatorname{sh} \kappa \mathrm{B} \zeta$ or the SHC002, each in combination with $\mathrm{I} \kappa \mathrm{B} \zeta$ or $\mathrm{mI} \kappa \mathrm{B} \zeta$. Samples were collected $24 \mathrm{~h}$ after transfection and exogenous I $\kappa \mathrm{B} \zeta \mathrm{mRNA}$ was quantified by RT-qPCR with primers that did not amplify the endogenous $\mathrm{I} \kappa \mathrm{B} \zeta$. Each value was normalized to the level of eGFP mRNA in that sample.

results in the release of proinflammatory cytokines and other inflammatory mediators ${ }^{93,94}$. Here we demonstrate a rapid increase in cytokine mRNA with the relatively faster increase in TNF $\alpha$ compared with IL6 being consistent with previous reports of the relative time courses of increased secreted TNF $\alpha$ and IL6 in response to MALP- $2^{95,96}$.

Our results show that M. arginini, M. fermentans and MALP-2 each stimulate the expression of TNF $\alpha$, IL6 and Lcn 2 expression in HC11 epithelial cells. TNF $\alpha$ and IL- 6 are regulated by C/EBP and NFkB as we show here for Lcn2. As for their mammary gland origin ${ }^{50}, \mathrm{HC} 11$ cells express several C/EBP isoforms. MALP-2 does not increase the expression of any isoform and we have located C/EBP $\beta$ in the nucleus where it and the other C/EBP isoforms are expected to be found. The sequence preferences of the $\mathrm{C} / \mathrm{EBP}$ isoforms for their binding elements are similar and the distinction of which isoform functions in a particular cell or tissue is determined by the isoform expression pattern ${ }^{97}$. Thus, more than one C/EBP is likely to be involved in regulating Lcn 2 gene expression in $\mathrm{HC} 11$ cells. We also note that the previous literature is controversial with respect to C/EBP involvement in regulating Lcn2. But, all previous studies of which we are aware have been done in cells lines of embryonic origin ${ }^{48,98}$ or tumor origin ${ }^{48,51,99}$. Ours is the only study to our knowledge of the regulation of Lcn2 expression in a cell line originating from a normal epithelial source.

Inflammatory stimuli can stimulate translocation of NFKB from the cytoplasm into the nucleus. Although both activators greatly increased the expression of Lcn 2 by HC11 cells, neither caused a large change in the distribution of NFKB. This observation is consistent with results already reported for untransformed epithelial cells. In H4-1 non-transformed human neonatal small intestinal cells only $10 \%$ or few (depending on the conditions) of these cells demonstrate NFKB translocation in response to a bacterial inflammatory stimulus ${ }^{100}$. By contrast, $\mathrm{NF \kappa B}$ was translocated into the nucleus of a majority of A549 cells ${ }^{101}$ and HeLa cells ${ }^{102}$. Thus, the translocation response of NFKB is context dependent and may be a more prominent feature of transformed cells than cells that display a normal phenotype.

In contrast to the rapid quenching of the TNF $\alpha$ and IL6 expression after activation by MALP-2, Lcn 2 expression continued to increase over $72 \mathrm{~h}$. Our data suggests that the extended period of response of Lcn 2 to MALP-2 is driven by the early increase in $\mathrm{I} \kappa \mathrm{B} \zeta$ expression, which activates secondary response genes but not primary response genes in macrophages and macrophage cell lines by a process that involves histone $\mathrm{H} 3 \mathrm{~K} 4$ trimethylation and results a persistent elevation in gene expression ${ }^{103}$. Epigenetic modification as a mechanism by which I $\kappa \mathrm{B} \zeta$ 
regulates Lcn2 expression is consistent with the observation that Lcn2 remained elevated for many hours after the removal of MALP-2.

The expression IL6 and TNF $\alpha$ was found to be constitutively elevated in cells chronically infected with mycoplasma, which is consistent with the observed persistence of the mammary inflammatory response to mycoplasma infections ${ }^{104}$ and suggests possible epigenetic changes in these genes in response to mycoplasma infection.

In summary, we have shown that mycoplasma and the mycoplasma-derived membrane lipopeptide, MALP-2, induce the expression of inflammatory response genes in epithelial cells. As well as contributing to chronic inflammation in vivo, the elevated expression of Lcn2 and cytokine genes in mycoplasma-infected cells reflects a inflammatory condition involving a subset of genes that alters the proteins expressed by the infected cells ${ }^{105}$, which can impact the outcomes of experiments performed with such cells in undefined ways and thus influence interpretation of the experimental results. The mechanism of Lcn2 induction in mammary epithelial cells by MALP-2 is similar to that in myeloid cells induced by LPS with the involvement of NFKB, C/EBP and $\mathrm{I} \kappa \mathrm{B} \zeta^{30,35,106}$. Compared with the brief period of increase in the cytokine genes in response to MALP-2, the Lcn2 response continues for at least $72 \mathrm{~h}$ and the elevated expression persists for long after the removal of MALP-2. We show by mutation and molecular manipulation that the presence of $\mathrm{I} \kappa \mathrm{B} \zeta$ and the proximal $\mathrm{NF} \kappa \mathrm{B}$ and $\mathrm{C} / \mathrm{EBP}$ transcription elements in the Lcn2 promoter are required for its activation.

\section{Materials and Methods}

Materials. LPS was from Sigma-Aldrich (St. Louis, MO) and MALP-2 was from Axxora (San Diego, CA). The $\mathrm{I} \kappa \mathrm{B} \zeta$ shRNA and SCH002 control plasmids were from Sigma (St. Louis, MO), the eGFP expression plasmid was from Clontech (Mountain View, CA) and pcDNA3.1 was from Invitrogen (Carlsbad, CA).

Cell culture. HC11 cells, a clone from the COMMA-D mouse mammary gland cell line $e^{47,107}$, were obtained from Dr. L. Sheffield (University of Wisconsin, Madison, Wisconsin) with permission of the cell line's originator, Dr. B. Groner Institute for Experimental Cancer, Freiburg, Germany, ${ }^{47}$ and cultured at $37^{\circ} \mathrm{C}$ in RPMI 1640 media (Sigma, St. Louis, MO) with 2\% FCS (Hyclone, Logan, UT), $5 \mu \mathrm{g} / \mathrm{ml}$ insulin (Sigma, St. Louis, MO), 10 units $/ \mathrm{ml}$ each of penicillin and streptomycin with $5 \% \mathrm{CO}_{2}$. Experiment treatments were in the same medium but with $0.1 \%$ FCS. HC11 cells were seeded in 6-well plates for $24 \mathrm{~h}$ in $2 \%$ FCS culture medium and then switched to $0.1 \%$ FCS culture medium. Sixteen hours later, MALP-2, LPS or the vehicle control were added to the medium. Cells were harvested at various times for RNA or protein analysis.

Mycoplasma detection, removal and infection. Genomic DNA, prepared using DNAzol (Invitrogen), was used as the template in PCR to detect mycoplasma. The primers in this reaction corresponded to a region of the $16 \mathrm{~S}$ rDNA that is highly conserved in mycoplasma ${ }^{108}$. The primer sequences were: sense ACCATGCACCAYCTGTCAYTC and anti-sense GAGCAAACAGGATTAGATAC. An internal reference control was included with every sample from which a band of $120 \mathrm{bp}$ was amplified. The samples were amplified for 28 cycles of $94^{\circ} \mathrm{C}$ for $30 \mathrm{sec}, 55^{\circ} \mathrm{C}$ for $60 \mathrm{sec}$, then $72{ }^{\circ} \mathrm{C}$ for $60 \mathrm{sec}$. A band of $280 \mathrm{bp}$ indicates mycoplasma contamination $^{108}$. This band and another region of the mycoplasma $16 \mathrm{~S}$ rDNA were sequenced from an infected cell culture and the mycoplasmal contaminant was identified as M. arginini.

Infected cell cultures were cleaned of $M$. arginini by treating the cells with three cycles of $10 \mu \mathrm{g} / \mathrm{ml} \mathrm{BM-cyclin}$ 1 (Roche Applied Science, Indianapolis, IN) for 3 days followed by $5 \mu \mathrm{g} / \mathrm{ml} \mathrm{BM-cyclin} 2$ (Roche) for 4 days. The cells were reinfected with $M$. arginini by exposing them to conditioned medium collected from an $M$. arginini infected cell culture that had been filtered through a $0.22 \mu \mathrm{m}$ sterilized filter. Mycoplasma-free HC11 cells were also infected with $M$. fermentans (ATCC, Manassas, VA). The infected cells were transferred for three passages before the mycoplasma could be detected by PCR amplification.

RNA extraction and reverse transcriptase quantitative PCR (RT-qPCR). Total RNA was extracted using the Trizol Reagent (Invitrogen, Carlsbad, CA) according to the manufacturer's instructions. The total RNA were dissolved in DEPC-treated $\mathrm{H}_{2} \mathrm{O}$, quantified by spectrophotometry and stored at $-80{ }^{\circ} \mathrm{C}$ until use. To remove contaminating DNA, $1 \mu \mathrm{g}$ total RNA was incubated for $15 \mathrm{~min}$ with 1 unit DNase (Invitrogen) then the DNase was inactivated by exposure to $70^{\circ} \mathrm{C}$ for $15 \mathrm{~min}$. Reverse transcription was done with Superscript II (Invitrogen) and an $18 \mathrm{nt}$ oligo dT as primer. qPCR was performed in an Opticon (MJ Research, Waltham, MA) using the FullVelocity ${ }^{\mathrm{TM}}$ QPCR Master Mix (Stratagene, La Jolla, CA). Levels of each mRNA gene product was normalized to the cyclophilin level in the same sample. Primers used in the experiments were 1) mouse Lcn 2 sense: AATGTCACCTCCATCCTGGTCA, anti-sense: GCGAACTGGTTGTAGTCCGTGGT; 2) cyclophilin sense: CTTTTCGCCGCTTGCTGCA, anti-sense: ACCACCCTGGCACATGAATCCT; 3 ) IL-6 sense: GAGGATACCACTCCCAACAGACC, anti-sense: AAGTGCATCATCGTTGTTCATACA; 4) TNF $\alpha$ sense: CATCTTCTCAAAATTCGAGTGACAA, anti-sense: TGGGAGTAGACAAGGTACAACCC; 5) I $\kappa \zeta$ sense: TGCAGAGGAATCGGCAGTCT, anti-sense: CGGACTGCGTCCAACTGTGT; 6) exogenous I $\kappa \zeta$ sense: CACCGCCCTCCATGTTGCT, anti-sense: GCAAACAACAGATGGCTGGCA; and 7) eGFP sense: ACAAGCAGAAGAACGGCATC, anti-sense: ACGAACTCCAGCAGGACCAT. For each mRNA analysis a standard curve was used to determine the quantity of the amplified cDNA in each sample. The standard curve was created by amplifying, under the same conditions as the cell-derived samples, a range of known amounts of PCR amplicons (from $10^{-6}$ to $8 \mathrm{pg} /$ well) using a template with the same sequence as present in the cDNA being quantified. Standard curves were plotted as $\log (\mathrm{pg} /$ well $)$ vs. $\mathrm{C}(\mathrm{t})$. Samples with $\mathrm{C}(\mathrm{t})$ 's outside the range of the standard curve were not included in the quantitative data and appropriate dilutions of the cDNA were reanalyzed to obtain quantitative values within the range of the standard curve.

Cloning. Mouse Lcn2 promoters of various lengths were prepared as PCR products from a mouse genomic BACmid (ES17526, Genomesystems Inc.) template. Fragments were inserted into the luciferase reporter 
plasmid pGL3-basic (Promega, Madison WI). Primers used for gene truncations were 1) -2108bp, sense: CAGACACAACAGAAGAGGGCAT, 2) -1477bp, sense: TGTGGGTTGTGTGAGGCTGTA, 3) -1003bp, sense: CAGGGCAGTGTGGAGACACA, 4) -711bp, sense: GCAGCCACATCTAAGGACTACG, 5) -438bp sense: GGTCTGGTGTTCAGATGGCTT), 6) -253bp sense TGCCTGCCAGAATCCAAAG, 7) - 197bp, sense: CAGCCCTTCCTGTTGCTCA, 8) - 108bp, sense: GCAATTACTTCATGGCTTCCTG, 9) - 253-NFкB,GGG/AAA: sense: TGCCTGCCAGAATCCAAAGCCCTAAAAATG with the same anti-sense oligonucleotide starting at $+53 \mathrm{bp}$ used for all: GGTTTCCACAGCTACTAGGTCTGA. Mutagenesis of the promoter was done using the Quickchange II kit (Stratagene) to convert the C/EBP binding site from CAGCCCTTCCTGTTGCTCAACCTTGCACAGTTCCGAC to CAGCCCTTCCTGGCACTTGGCCTTGCACAGTTCCGAC and/or the NFkB binding site from GCCCTGGGAATG to GCCCTAAAAATG where the changed bases are underlined.

Human Lcn2 (NGAL) promoters of various lengths were also inserted into pGL3-basic. -1690 bp was amplified with sense: AGTCGGTACCGATCTCGGCTCACTGCAAC and anti-sense: GTCACTCGAGGCAGGCGCTGTGGTG $(+51)$ using pNGP1695CAT (kindly donated by N. Borregaard) as template. $-264 \mathrm{bp}$ was amplified from human genomic DNA (extracted from human HCT-8 cells) with sense: AGTCGGTACCCCACATACAGGGCAATCAGA and anti-sense: GTCACTCGAGGATTTCAGGGCCGAGGAAG $(+69)$. The Quickchange II kit was used to introduce mutations: the NFKB binding site from AGGTGCAGCACTCCGGGAATGTCCCTCACTCT to AGGTGCAGCACTCCAAAAATGTCCCTCACTCT; the C/EBP binding site from CCCGTCCCTCTGTCTTGCCCAATCCTGACCAGGTGCAG to CCCGTCCCTCTGTCGCACCTGGTCCTGACCAGGTGCAG with the changed bases underlined.

$\mathrm{I} \kappa \mathrm{B} \zeta \mathrm{cDNA}$ was amplified from a preparation of HC11 RNA and cloned into pcDNA3.1(-) (Invitrogen). A silent mutation in the region that is complementary to $s h \operatorname{I} \kappa B \zeta$ in the wildtype mRNA was created using the Quickchange II kit (Stratagene) to convert the sequence GCCCTGCTTCAGAATATTATA to GCCCTGCTCCAAAAㅡㅅTTATA in which the changed bases are underlined.

Luciferase assay. To measure the activities of the Lcn2 promoter and its truncations, HC11 cells were co-transfected using Lipofectamine 2000 (Invitrogen), with the appropriate promoter-luciferase reporter plasmids in combination with the plasmid pRLSV-40 (Promega) from which the Renilla luciferase is expressed under the control of the SV 40 promoter. The activities of the two luciferases were quantified by the Dual Luciferase assay (Promega) using a Glomax 20/20 luminometer (Promega). The Renilla luciferase activity provides an internal control for the cell lysate content of the sample. The measure of promoter activity was calculated by dividing the firefly luciferase activity by the Renilla luciferase activity in each sample.

Statistical and quantitative analysis. Triplicate independently treated samples were quantified for RT-qPCR or luciferase and the average of the three values were taken as the result for that treatment or condition. All results shown were tested with at least two and up to 7 independently performed experiments in which similar results were obtained. The error bars show the standard deviations of the means.

\section{Data availability}

All data on which this work is based is available upon request to $\mathrm{MNH}$.

Received: 27 August 2019; Accepted: 25 March 2020;

Published online: 06 May 2020

\section{References}

1. Yamazaki, S., Muta, T. \& Takeshige, K. A novel IkappaB protein, IkappaB-zeta, induced by proinflammatory stimuli, negatively regulates nuclear factor-kappaB in the nuclei. J. Biol. Chem. 276, 27657-27662, https://doi.org/10.1074/jbc.M103426200 (2001).

2. Haruta, H., Kato, A. \& Todokoro, K. Isolation of a novel interleukin-1-inducible nuclear protein bearing ankyrin-repeat motifs. J. Biol. Chem. 276, 12485-12488, https://doi.org/10.1074/jbc.C100075200 (2001).

3. Kitamura, H., Kanehira, K., Okita, K., Morimatsu, M. \& Saito, M. MAIL, a novel nuclear I kappa B protein that potentiates LPSinduced IL-6 production. FEBS Lett. 485, 53-56, https://doi.org/10.1016/s0014-5793(00)02185-2 (2000).

4. Playford, R. J. et al. Effects of Mouse and Human Lipocalin Homologues $24 \mathrm{p} 3 / \mathrm{lcn} 2$ and Neutrophil Gelatinase-Associated Lipocalin on Gastrointestinal Mucosal Integrity and Repair. Gastroenterology 131, 809-817, https://doi.org/10.1053/j. gastro.2006.05.051 (2006).

5. Sola, A. et al. Sphingosine-1-phosphate signalling induces the production of Lcn-2 by macrophages to promote kidney regeneration. J. Pathol. 225, 597-608, https://doi.org/10.1002/path.2982 (2011).

6. Cai, L., Rubin, J., Han, W., Venge, P. \& Xu, S. The Origin of Multiple Molecular Forms in Urine of HNL/NGAL. Clin. J. Am. Soc. Nephrology 5, 2229-2235, https://doi.org/10.2215/cin.00980110 (2010).

7. Liu, Q. \& Nilsen-Hamilton, M. Identification of a new acute phase protein. J. Biol. Chem. 270, 22565-22570, https://doi. org/10.1074/jbc.270.38.22565 (1995).

8. Liu, Q., Ryon, J. \& Nilsen-Hamilton, M. Uterocalin: A mouse acute phase protein expressed in the uterus around birth. Mol. Reprod. Dev. 46, 507-514, 10.1002/(SICI) 1098-2795(199704)46:4<507::AID-MRD9>3.0.CO;2-S (1997).

9. Ryon, J., Bendickson, L. \& Nilsen-Hamilton, M. High expression in involuting reproductive tissues of uterocalin/24p3, a lipocalin and acute phase protein. Biochemical J. 367, 271-277, https://doi.org/10.1042/BJ20020026 (2002).

10. Nilsen-Hamilton, M. et al. Tissue involution and the acute phase response. Ann. N. Y. Acad. Sci. 995, 94-108, https://doi. org/10.1111/j.1749-6632.2003.tb03213.x (2003).

11. Sunil, V. R. et al. Acute endotoxemia is associated with upregulation of lipocalin $24 \mathrm{p} 3 / \mathrm{Lcn} 2$ in lung and liver. Exp. Mol. Pathol. 83, 177-187, https://doi.org/10.1016/j.yexmp.2007.03.004 (2007).

12. Hopfe, M., Deenen, R., Degrandi, D., Köhrer, K. \& Henrich, B. Host cell responses to persistent mycoplasmas-different stages in infection of HeLa cells with Mycoplasma hominis. PLoS One 8, e54219, https://doi.org/10.1371/journal.pone.0054219 (2013).

13. Waites, K. B., Xiao, L., Liu, Y., Balish, M. F. \& Atkinson, T. P. Mycoplasma pneumoniae from the Respiratory Tract and Beyond. Clin. microbiology Rev. 30, 747-809, https://doi.org/10.1128/cmr.00114-16 (2017).

14. Bürki, S., Frey, J. \& Pilo, P. Virulence, persistence and dissemination of Mycoplasma bovis. Veterinary Microbiology 179, 15-22, https://doi.org/10.1016/j.vetmic.2015.02.024 (2015). 
15. Rogers, M. B. Mycoplasma and cancer: in search of the link. Oncotarget 2, 271-273, https://doi.org/10.18632/oncotarget.264 (2011).

16. Vande Voorde, J., Balzarini, J. \& Liekens, S. Mycoplasmas and cancer: focus on nucleoside metabolism. EXCLI journal 13, 300-322, NA (2014).

17. Choi, H. S. et al. Detection of mycoplasma infection in circulating tumor cells in patients with hepatocellular carcinoma. Biochem. Biophys. Res. Commun. 446, 620-625, https://doi.org/10.1016/j.bbrc.2014.03.024 (2014).

18. Duan, H. et al. Mycoplasma Hyorhinis Infection Promotes NF-B-Dependent Migration of Gastric Cancer Cells. Cancer Res. 74, 5782-5794, https://doi.org/10.1158/0008-5472.can-14-0650 (2014).

19. Duan, H., Qu, L. \& Shou, C. Mycoplasma hyorhinis induces epithelial-mesenchymal transition in gastric cancer cell MGC803 via TLR4-NF-кB signaling. Cancer Lett. 354, 447-454, https://doi.org/10.1016/j.canlet.2014.08.018 (2014).

20. Patil, S., Rao, R. S. \& Raj, A. T. Role of Mycoplasma in the Initiation and Progression of Oral Cancer. Journal of international oral health 7 , i-ii, not assigned (2015).

21. Cao, S. et al. Potential malignant transformation in the gastric mucosa of immunodeficient mice with persistent Mycoplasma penetrans infection. PLoS One 12, e0180514, https://doi.org/10.1371/journal.pone.0180514 (2017).

22. Ikehata, N. et al. Toll-like receptor 2 activation implicated in oral squamous cell carcinoma development. Biochem. Biophys. Res. Commun. 495, 2227-2234, https://doi.org/10.1016/j.bbrc.2017.12.098 (2018).

23. Ye, H. et al. Association between genital mycoplasmas infection and human papillomavirus infection, abnormal cervical cytopathology, and cervical cancer: a systematic review and meta-analysis. Arch. Gynecol. Obstet. 297, 1377-1387, https://doi. org/10.1007/s00404-018-4733-5 (2018).

24. Zella, D. et al. Mycoplasma promotes malignant transformation in vivo, and its DnaK, a bacterial chaperone protein, has broad oncogenic properties. Proc. Natl Acad. Sci. USA 115, E12005-E12014, https://doi.org/10.1073/pnas.1815660115 (2018).

25. Zarei, O., Rezania, S. \& Mousavi, A. Mycoplasma genitalium and cancer: a brief review. Asian Pac. J. Cancer Prev. 14, 3425-3428, https://doi.org/10.7314/apjcp.2013.14.6.3425 (2013).

26. Miyake, M. et al. Mycoplasma genitalium Infection and Chronic Inflammation in Human Prostate Cancer: Detection Using Prostatectomy and Needle Biopsy Specimens. Cells 8, 212, https://doi.org/10.3390/cells8030212 (2019).

27. Barykova, Y. A. et al. Association of Mycoplasma hominis infection with prostate cancer. Oncotarget 2, 289-297, https://doi. org/10.18632/oncotarget.256 (2011).

28. Mitin, V., Tumanova, L. \& Botnariuc, N. Mycoplasma Faucium and Breast Cancer. bioRxiv, 089128, https://doi.org/10.1101/089128 (2016).

29. Razin, S., Yogev, D. \& Naot, Y. Molecular biology and pathogenicity of mycoplasmas. Microbiology and molecular biology reviews 62, 1094-1156, not assigned (1998).

30. Galanos, C., Gumenscheimer, M., Muhlradt, P., Jirillo, E. \& Freudenberg, M. MALP-2, a Mycoplasma lipopeptide with classical endotoxic properties: end of an era of LPS monopoly? J. Endotoxin Res. 6, 471-476 (2000).

31. Knorr, C. et al. Macrophage-activating lipopeptide-2 (MALP-2) induces a localized inflammatory response in rats resulting in activation of brain sites implicated in fever. Brain Res. 1205, 36-46, https://doi.org/10.1016/j.brainres.2008.02.021 (2008).

32. Seya, T. \& Matsumoto, M. A lipoprotein family from Mycoplasma fermentans confers host immune activation through Toll-like receptor 2. Int. J. Biochem. Cell Biol. 34, 901-906 (2002).

33. Takeda, Y. et al. Type I Interferon-Independent Dendritic Cell Priming and Antitumor T Cell Activation Induced by a Mycoplasma fermentans Lipopeptide. Front. Immunol. 9, 496-496, https://doi.org/10.3389/fimmu.2018.00496 (2018).

34. Xu, Y. et al. Mycoplasma hyorhinis activates the NLRP3 inflammasome and promotes migration and invasion of gastric cancer cells. PLoS One 8, e77955, https://doi.org/10.1371/journal.pone.0077955 (2013).

35. Deiters, U., Gumenscheimer, M., Galanos, C. \& Muhlradt, P. F. Toll-like receptor 2- and 6-mediated stimulation by macrophageactivating lipopeptide 2 induces lipopolysaccharide (LPS) cross tolerance in mice, which results in protection from tumor necrosis factor alpha but in only partial protection from lethal LPS doses. Infect. Immun. 71, 4456-4462, https://doi.org/10.1128/ iai.71.8.4456-4462.2003 (2003)

36. Luhrmann, A. et al. In vivo effects of a synthetic 2-kilodalton macrophage-activating lipopeptide of Mycoplasma fermentans after pulmonary application. Infect. Immun. 70, 3785-3792, https://doi.org/10.1128/iai.70.7.3785-3792.2002 (2002).

37. Omueti, K. O., Beyer, J. M., Johnson, C. M., Lyle, E. A. \& Tapping, R. I. Domain exchange between human toll-like receptors 1 and 6 reveals a region required for lipopeptide discrimination. J. Biol. Chem. 280, 36616-36625, https://doi.org/10.1074/jbc. M504320200 (2005)

38. Rharbaoui, F. et al. The Mycoplasma-derived lipopeptide MALP-2 is a potent mucosal adjuvant. Eur J Immunol 32, 2857-2865, 10.1002/1521-4141(2002010)32:10<2857::AID-IMMU2857>3.0.CO;2-R (2002).

39. Borchsenius, S. N., Daks, A., Fedorova, O., Chernova, O. \& Barlev, N. A. Effects of mycoplasma infection on the host organism response via p53/NF-kB signaling. J. Cell. Physiol. 234, 171-180, https://doi.org/10.1002/jcp.26781 (2019).

40. Gedye, C. et al. Mycoplasma Infection Alters Cancer Stem Cell Properties in Vitro. Stem Cell Rev. Rep. 12, 156-161, https://doi. org/10.1007/s12015-015-9630-8 (2016).

41. Zhang, H.-B., Fan, J.-M., Zhu, L.-L., Yuan, X.-H. \& Shen, X.-W. Combination of NGAL and Cystatin C for Prediction of Preeclampsia at 10-14 Weeks of Gestation. Clin Lab 65, NA, https://doi.org/10.7754/Clin.Lab.2018.180831 (2019).

42. Tang, X.-Y. et al. Urine NGAL as an early biomarker for diabetic kidney disease: accumulated evidence from observational studies. Ren. Fail. 41, 446-454, https://doi.org/10.1080/0886022x.2019.1617736 (2019).

43. Lu, J. et al. Serum NGAL Is Superior to Cystatin C in Predicting the Prognosis of Acute-on-Chronic Liver Failure. Ann. Hepatology 18, 155-164, https://doi.org/10.5604/01.3001.0012.7907 (2019).

44. Asimakopoulou, A., Borkham-Kamphorst, E., Tacke, F. \& Weiskirchen, R. Lipocalin-2 (NGAL/LCN2), a "help-me" signal in organ inflammation. Hepatology 63, 669-671, https://doi.org/10.1002/hep.27930 (2016).

45. Abella, V. et al. The potential of lipocalin-2/NGAL as biomarker for inflammatory and metabolic diseases. Biomarkers 20, 565-571, https://doi.org/10.3109/1354750x.2015.1123354 (2015).

46. Hynes, N. E. et al. Epidermal growth factor receptor, but not c-erbB-2, activation prevents lactogenic hormone induction of the beta-casein gene in mouse mammary epithelial cells. Mol. Cell Biol. 10, 4027-4034, https://doi.org/10.1128/mcb.10.8.4027 (1990).

47. Ball, R. K., Friis, R. R., Schoenenberger, C. A., Doppler, W. \& Groner, B. Prolactin regulation of beta-casein gene expression and of a cytosolic 120-kd protein in a cloned mouse mammary epithelial cell line. EMBO J. 7, 2089-2095 (1988).

48. Matsuo, S., Yamazaki, S., Takeshige, K. \& Muta, T. Crucial roles of binding sites for NF-kappaB and C/EBPs in IkappaB-zetamediated transcriptional activation. Biochem. J. 405, 605-615, https://doi.org/10.1042/BJ20061797 (2007).

49. Cowland, J. B., Muta, T. \& Borregaard, N. IL-1beta-specific up-regulation of neutrophil gelatinase-associated lipocalin is controlled by IkappaB-zeta. J. Immunol. 176, 5559-5566, https://doi.org/10.4049/jimmunol.176.9.5559 (2006).

50. Zahnow, C. A. CCAAT/enhancer binding proteins in normal mammary development and breast cancer. Breast Cancer Res. 4 , 113-121, https://doi.org/10.1186/bcr428 (2002).

51. Karlsen, J. R., Borregaard, N. \& Cowland, J. B. Induction of Neutrophil Gelatinase-associated Lipocalin Expression by Costimulation with Interleukin-17 and Tumor Necrosis Factor- $\alpha$ Is Controlled by I $\kappa$ B- $\zeta$ but neither by C/EBP- $\beta$ nor C/EBP- $\delta$. J. Biol. Chem. 285, 14088-14100, https://doi.org/10.1074/jbc.M109.017129 (2010).

52. Bolignano, D., Coppolino, G., Lacquaniti, A. \& Buemi, M. From kidney to cardiovascular diseases: NGAL as a biomarker beyond the confines of nephrology. Eur. J. Clin. Invest. 40, 273-276, https://doi.org/10.1111/j.1365-2362.2010.02258.x (2010). 
53. Paragas, N. et al. The Ngal reporter mouse detects the response of the kidney to injury in real time. Nat. Med. 17, 216-222, https:// doi.org/10.1038/nm.2290 (2011).

54. Cernaro, V. et al. NGAL is a precocious marker of therapeutic response. Curr. Pharm. Des. 17, 844-849, https://doi. org/10.2174/138161211795428939 (2011).

55. McMahon, B. A. et al. Biomarker Predictors of Adverse Acute Kidney Injury Outcomes in Critically Ill Patients: The Dublin Acute Biomarker Group Evaluation Study. Am. J. Nephrology 50, 19-28, https://doi.org/10.1159/000500231 (2019).

56. Park, H. S. et al. Urinary neutrophil gelatinase-associated lipocalin as a biomarker of acute kidney injury in sepsis patients in the emergency department. Clinica Chim. Acta 495, 552-555, https://doi.org/10.1016/j.cca.2019.06.005 (2019).

57. Tidbury, N. et al. Neutrophil gelatinase-associated lipocalin as a marker of postoperative acute kidney injury following cardiac surgery in patients with pre-operative kidney impairment. Cardiovasc. Hematol. Disord. Drug. Targets 19, 1-10, https://doi.org/10 $.2174 / 1871529 X 19666190415115106(2019)$.

58. Zhou, F., Luo, Q., Wang, L. \& Han, L. Diagnostic value of neutrophil gelatinase-associated lipocalin for early diagnosis of cardiac surgery-associated acute kidney injury: a meta-analysis. Eur. J. Cardio-Thoracic Surg. 49, 746-755, https://doi.org/10.1093/ejcts/ ezv199 (2016).

59. Urbschat, A., Obermüller, N. \& Haferkamp, A. Biomarkers of kidney injury. Biomarkers 16, S22-S30, https://doi.org/10.3109/135 4750X.2011.587129 (2011)

60. Hamilton, R. T., Nilsen-Hamilton, M. \& Adams, G. Superinduction by cycloheximide of mitogen-induced secreted proteins produced by Balb/c 3T3 cells. J. Cell Physiol. 123, 201-208, https://doi.org/10.1002/jcp.1041230208 (1985).

61. Nilsen-Hamilton, M., Hamilton, R. T. \& Adams, G. A. Rapid selective stimulation by growth factors of the incorporation by BALB/C 3T3 cells of [35S]methionine into a glycoprotein and five superinducible proteins. Biochem. Biophys. Res. Commun. 108, 158-166, https://doi.org/10.1016/0006-291x(82)91845-9 (1982).

62. Cowland, J. B., Sorensen, O. E., Sehested, M. \& Borregaard, N. Neutrophil gelatinase-associated lipocalin is up-regulated in human epithelial cells by IL-1 beta, but not by TNF-alpha. J. Immunol. 171, 6630-6639, https://doi.org/10.4049/jimmunol.171.12.6630 (2003).

63. Orabona, C., Dumoutier, L. \& Renauld, J. C. Interleukin-9 induces $24 \mathrm{P} 3$ lipocalin gene expression in murine T cell lymphomas. Eur. Cytokine Netw. 12, 154-161 (2001)

64. Liu, Q. S., Nilsen-Hamilton, M. \& Xiong, S. D. Synergistic regulation of the acute phase protein SIP24/24p3 by glucocorticoid and pro-inflammatory cytokines. Sheng Li Xue Bao 55, 525-529 (2003).

65. Zerega, B., Cermelli, S., Michelis, B., Cancedda, R. \& Cancedda, F. D. Expression of NRL/NGAL (neu-related lipocalin/neutrophil gelatinase-associated lipocalin) during mammalian embryonic development and in inflammation. Eur J Cell Biol 79, 165-172, doi:not assigned (2000).

66. Vizzardelli, C. et al. Effects of dexamethazone on LPS-induced activation and migration of mouse dendritic cells revealed by a genome-wide transcriptional analysis. Eur. J. Immunol. 36, 1504-1515, https://doi.org/10.1002/eji.200535488 (2006).

67. Garay-Rojas, E., Harper, M., Hraba-Renevey, S. \& Kress, M. An apparent autocrine mechanism amplifies the dexamethasone- and retinoic acid-induced expression of mouse lipocalin-encoding gene 24p3. Gene 170, 173-180, https://doi.org/10.1016/03781119(95)00896-9 (1996).

68. Du, X., Poltorak, A., Silva, M. \& Beutler, B. Analysis of Tlr4-Mediated LPS Signal Transduction in Macrophages by Mutational Modification of the Receptor. Blood Cells, Molecules, Dis. 25, 328-338, https://doi.org/10.1006/bcmd.1999.0262 (1999).

69. Kitchens, R. L. \& Munford, R. S. Enzymatically deacylated lipopolysaccharide (LPS) can antagonize LPS at multiple sites in the LPS recognition pathway. J. Biol. Chem. 270, 9904-9910, https://doi.org/10.1074/jbc.270.17.9904 (1995).

70. Huggins, T. et al. Quantitation of endotoxin and lipoteichoic acid virulence using toll receptor reporter gene. Am. J. Dent. 29, 321-327 (2016)

71. Muhlradt, P. F., Kiess, M., Meyer, H., Sussmuth, R. \& Jung, G. Isolation, structure elucidation, and synthesis of a macrophage stimulatory lipopeptide from Mycoplasma fermentans acting at picomolar concentration. J. Exp. Med. 185, 1951-1958, https://doi. org/10.1084/jem.185.11.1951 (1997)

72. Borregaard, N., Sehested, M., Nielsen, B. S., Sengelov, H. \& Kjeldsen, L. Biosynthesis of granule proteins in normal human bone marrow cells. Gelatinase is. a marker terminal neutrophil differentiation. Blood 85, 812-817 (1995).

73. Flo, T. H. et al. Lipocalin 2 mediates an innate immune response to bacterial infection by sequestrating iron. Nature 432, 917-921, https://doi.org/10.1038/nature03104 (2004).

74. Srisawat, N., Murugan, R. \& Kellum, J. A. Repair or progression after AKI: a role for biomarkers? Nephron Clin. Pract. 127, 185-189, https://doi.org/10.1159/000363254 (2014).

75. Rebalka, I. A. et al. Loss of the adipokine lipocalin-2 impairs satellite cell activation and skeletal muscle regeneration. Am. J. Physiol. Cell Physiol 315, C714-C721, https://doi.org/10.1152/ajpcell.00195.2017 (2018).

76. Thorsvik, S. et al. Ulcer-associated cell lineage expresses genes involved in regeneration and is hallmarked by high neutrophil gelatinase-associated lipocalin (NGAL) levels. J. Pathol. 248, 316-325, https://doi.org/10.1002/path.5258 (2019).

77. Jin, D., Zhang, Y. \& Chen, X. Lipocalin 2 deficiency inhibits cell proliferation, autophagy, and mitochondrial biogenesis in mouse embryonic cells. Mol. Cell Biochem. 351, 165-172, https://doi.org/10.1007/s11010-011-0724-6 (2011).

78. Devireddy, L. R., Teodoro, J. G., Richard, F. A. \& Green, M. R. Induction of apoptosis by a secreted lipocalin that is transcriptionally regulated by Il-3 deprivation. Science 293, 829-834, https://doi.org/10.1126/science.1061075 (2001).

79. Liu, Z. et al. Multiple apoptotic defects in hematopoietic cells from mice lacking lipocalin 24p3. J. Biol. Chem. 286, 20606-20614, https://doi.org/10.1074/jbc.M110.216549 (2011).

80. Wang, Y.-P. et al. Lipocalin-2 negatively modulates the epithelial-to-mesenchymal transition in hepatocellular carcinoma through the epidermal growth factor (TGF-beta1)/Lcn2/Twist1 pathway. Hepatology 58, 1349-1361, https://doi.org/10.1002/hep.26467 (2013).

81. Liao, C.-J., Li, P.-T., Lee, Y.-C., Li, S.-H. \& Chu, S. T. Lipocalin 2 induces the epithelial-mesenchymal transition in stressed endometrial epithelial cells: possible correlation with endometriosis development in a mouse model. Reproduction 147, 179-187, https://doi.org/10.1530/rep-13-0236 (2014).

82. Lim, R. et al. Neutrophil gelatinase-associated lipocalin (NGAL) an early-screening biomarker for ovarian cancer: NGAL is associated with epidermal growth factor-induced epithelio-mesenchymal transition. Int. J. Cancer 120, 2426-2434, https://doi. org/10.1002/ijc.22352 (2007)

83. Nguyen, V. T. et al. Cutaneous wound healing in diabetic mice is improved by topical mineralocorticoid receptor blockade. Journal of Investigative Dermatology, https://doi.org/10.1016/j.jid.2019.04.030 (2019).

84. Peltier, M. R., Richey, L. J. \& Brown, M. B. Placental lesions caused by experimental infection of Sprague-Dawley rats with Mycoplasma pulmonis. Am. J. Reprod. Immunol. 50, 254-262 (2003).

85. Kennedy, S. \& Ball, H. J. Pathology of experimental ureaplasma mastitis in ewes. Vet. Pathol. 24, 302-307, https://doi. org/10.1177/030098588702400403 (1987).

86. Rollins, S., Colby, T. \& Clayton, F. Open lung biopsy in Mycoplasma pneumoniae pneumonia. Arch. Pathol. Lab. Med. 110, 34-41 (1986).

87. Lindsey, J. R. \& Cassell, H. Experimental Mycoplasma pulmonis infection in pathogen-free mice. Models for studying mycoplasmosis of the respiratory tract. Am. J. Pathol. 72, 63-90 (1973). 
88. Ibeagha-Awemu, E. M. et al. Bacterial lipopolysaccharide induces increased expression of toll-like receptor (TLR) 4 and downstream TLR signaling molecules in bovine mammary epithelial cells. Vet. Res. 39, 11, https://doi.org/10.1051/vetres:2007047 (2008).

89. Pandey, S. \& Agrawal, D. K. Immunobiology of Toll-like receptors: emerging trends. Immunol. Cell Biol. 84, 333-341, https://doi. org/10.1111/j.1440-1711.2006.01444.x (2006).

90. Furrie, E., Macfarlane, S., Thomson, G. \& Macfarlane, G. T. Toll-like receptors-2, -3 and -4 expression patterns on human colon and their regulation by mucosal-associated bacteria. Immunology 115, 565-574, https://doi.org/10.1111/j.1365-2567.2005.02200.x (2005).

91. Muhlradt, P. F. \& Frisch, M. Purification and partial biochemical characterization of a Mycoplasma fermentans-derived substance that activates macrophages to release nitric oxide, tumor necrosis factor, and interleukin-6. Infect. Immun. 62, 3801-3807 (1994).

92. Morr, M., Takeuchi, O., Akira, S., Simon, M. M. \& Muhlradt, P. F. Differential recognition of structural details of bacterial lipopeptides by toll-like receptors. Eur J Immunol 32, 3337-3347, 10.1002/1521-4141(200212)32:12<3337::AIDIMMU3337>3.0.CO;2-\# (2002).

93. Nathan, C. Points of control in inflammation. Nature 420, 846-852, https://doi.org/10.1038/nature01320 (2002).

94. Mellman, I. \& Steinman, R. M. Dendritic cells: specialized and regulated antigen processing machines. Cell 106, 255-258, https:// doi.org/10.1016/s0092-8674(01)00449-4 (2001).

95. Barrenschee, M., Lex, D. \& Uhlig, S. Effects of the TLR2 Agonists MALP-2 and Pam3Cys in Isolated Mouse Lungs. PLoS One 5, e13889, https://doi.org/10.1371/journal.pone.0013889 (2010).

96. Kaufmann, A., Muhlradt, P. F., Gemsa, D. \& Sprenger, H. Induction of cytokines and chemokines in human monocytes by Mycoplasma fermentans-derived lipoprotein MALP-2. Infect. Immun. 67, 6303-6308 (1999).

97. Osada, S., Yamamoto, H., Nishihara, T. \& Imagawa, M. DNA Binding Specificity of the CCAAT/Enhancer-binding Protein Transcription Factor Family. J. Biol. Chem. 271, 3891-3896, https://doi.org/10.1074/jbc.271.7.3891 (1996).

98. Gombart, A. F. et al. Regulation of neutrophil and eosinophil secondary granule gene expression by transcription factors C/EBP epsilon and PU.1. Blood 101, 3265-3273, https://doi.org/10.1182/blood-2002-04-1039 (2003).

99. Du, Z.-P. et al. Neutrophil gelatinase-associated lipocalin in gastric carcinoma cells and its induction by TPA are controlled by C/ EBP3. Biochem. Cell Biol. 89, 314-324, https://doi.org/10.1139/o11-002 (2011)

100. Trapecar, M., Goropevsek, A., Gorenjak, M., Gradisnik, L. \& Slak Rupnik, M. A co-culture model of the developing small intestine offers new insight in the early immunomodulation of enterocytes and macrophages by Lactobacillus spp. through STAT1 and NFkB p65 translocation. PLoS One 9, e86297, https://doi.org/10.1371/journal.pone.0086297 (2014).

101. Wright, F. L. et al. Hyperosmolarity invokes distinct anti-inflammatory mechanisms in pulmonary epithelial cells: evidence from signaling and transcription layers. PLoS One 9, e114129-e114129, https://doi.org/10.1371/journal.pone.0114129 (2014).

102. Trask, O. J. Jr. Nuclear Factor Kappa B (NF-kappaB) Translocation Assay Development and Validation for High Content Screening. NBK100914 [bookaccession] (2004).

103. Kayama, H. et al. Class-specific regulation of pro-inflammatory genes by MyD88 pathways and IkappaBzeta. J. Biol. Chem. 283, 12468-12477, https://doi.org/10.1074/jbc.A115.709965 (2008).

104. Kauf, A. C., Vinyard, B. T. \& Bannerman, D. D. Effect of intramammary infusion of bacterial lipopolysaccharide on experimentally induced Staphylococcus aureus intramammary infection. Res. Vet. Sci. 82, 39-46, https://doi.org/10.1016/j.rvsc.2006.05.006 (2007).

105. Hoff, F. W. et al. Mycoplasma contamination of leukemic cell lines alters protein expression determined by reverse phase protein arrays. Cytotechnology 70, 1529-1535, https://doi.org/10.1007/s10616-018-0244-2 (2018).

106. Yamamoto, M. et al. Regulation of Toll/IL-1-receptor-mediated gene expression by the inducible nuclear protein IkappaBzeta. Nature 430, 218-222, https://doi.org/10.1038/nature02738 (2004).

107. Danielson, K. G., Oborn, C. J., Durban, E. M., Butel, J. S. \& Medina, D. Epithelial mouse mammary cell line exhibiting normal morphogenesis in vivo and functional differentiation in vitro. Proc. Natl Acad. Sci. USA 81,3756-3760 (1984).

108. Bruchmuller, I. et al. Introduction of a validation concept for a PCR-based Mycoplasma detection assay. Cytotherapy 8, 62-69, https://doi.org/10.1080/14653240500518413 (2006).

\section{Acknowledgements}

The experiments reported here also feature in the doctoral thesis of W.Z (https://lib.dr.iastate.edu/etd/10585). We thank Dr. Alan Miller for providing use of the luminometer and Drs. Tianjiao Wang and Xiaoling Song for their useful suggestions. This work was funded in part by the Agricultural Experiment Station of Ames, Iowa, project NE1009 and NIH grant R21 AI114283.

\section{Author contributions}

W.Z. and L.B. performed the experimental studies with the majority performed by W.Z. who also conceived of and designed the experiments. W.Z. wrote the first draft of the manuscript. M.N.H. initiated the project, directed the work, revised and completed preparation of the manuscript. All authors participated in revisions of the manuscript and reviewed the final version of the manuscript.

\section{Competing interests}

The authors declare no competing interests.

\section{Additional information}

Supplementary information is available for this paper at https://doi.org/10.1038/s41598-020-63393-x.

Correspondence and requests for materials should be addressed to M.N.-H.

Reprints and permissions information is available at www.nature.com/reprints.

Publisher's note Springer Nature remains neutral with regard to jurisdictional claims in published maps and institutional affiliations. 
(c) (i) Open Access This article is licensed under a Creative Commons Attribution 4.0 International License, which permits use, sharing, adaptation, distribution and reproduction in any medium or format, as long as you give appropriate credit to the original author(s) and the source, provide a link to the Creative Commons license, and indicate if changes were made. The images or other third party material in this article are included in the article's Creative Commons license, unless indicated otherwise in a credit line to the material. If material is not included in the article's Creative Commons license and your intended use is not permitted by statutory regulation or exceeds the permitted use, you will need to obtain permission directly from the copyright holder. To view a copy of this license, visit http://creativecommons.org/licenses/by/4.0/.

(C) The Author(s) 2020 